\title{
Measuring the effect of managerial ability on earning quality
}

\author{
Jamal Bahri Sales ${ }^{\mathrm{a}}$, Atabak Baybordi ${ }^{\mathrm{b} *}$, Mohammad Naghizadeh Aydenlu ${ }^{\mathrm{c}}$ and Niloofar Asaldoost ${ }^{\mathrm{d}}$
}

${ }^{a} \mathrm{PhD}$, Assistant Professor of Accounting \& Finance; School of Humanities, Department of Accounting \& Finance, Urmia Branch, Islamic Azad University, Urmia, Iran

${ }^{b}$ PhD Student, Assistant Professor of Accounting \& Finance; School of Humanities, Department of Accounting \& Finance, Urmia Branch, Islamic Azad University, Urmia, Iran

${ }^{c} \mathrm{PhD}$, School of Humanities, Department of Accounting \& Finance, Urmia Branch, Islamic Azad University, Urmia, Iran

${ }^{d}$ Master's student in Management, Iran

\section{H R O N I C L E}

\begin{tabular}{l}
\hline Article history: \\
Received March 25, 2015 \\
Received in revised format June \\
102015 \\
Accepted July 102015 \\
Available online \\
July 142015 \\
\hline Keywords: \\
Tehran Stock Exchange \\
Managerial ability \\
Earning quality
\end{tabular}

\begin{abstract}
A B S T R A C T
This paper presents an empirical investigation to measure the effect of managerial ability on earning quality on selected firms listed on Tehran Stock Exchange over the period 2007-2013. The proposed study uses data envelopment analysis to measure the relative efficiency of selected firms where Sales is considered as output and Cost of goods (COGS), Selling, General and Administrative Expenses (SG\&A), Net Property Plant and Equipment (PPE), Net operating Leases (OpsLease), Research \& Development (R\&D), Purchased Good will (Goodwill) and Other intangible assets (OtherIntan) are considered as inputs. Earning quality in this survey consists of three parts of quality of accruals, earnings and earnings forecast persistence. The results of our survey have indicated that managerial ability influences positively on earning quality.
\end{abstract}

\section{Introduction}

During the past few years, there have been many studies on measuring the effects of managerial ability on profitability. Demerjian et al. (2012) proposed a technique of managerial ability, based on managers' efficiency in generating revenues, which is used for a big sample of companies and outperformed existing capability measures. They reported that their measure was strongly associated with manager fixed effects and that the stock price reactions to chief executive officer (CEO) turnovers were positive (negative) when they assessed the outgoing CEO as low (high) ability. They also reported that replacing CEOs with more (less) able CEOs was associated with improvements (declines) in subsequent firm performance. They concluded with a demonstration of the potential of the measure. They reported that the negative relation between equity financing and future abnormal returns reported in prior research was mitigated by managerial ability. Specifically, more able managers seemed to utilize equity issuance

\footnotetext{
* Corresponding author.
}

E-mail address: atabak.baybordi@gmail.com (A. Baybordi) 
proceeds more effectively, illustrating that their more precise measure of managerial ability would allow researchers to pursue studies that were previously difficult to conduct. Silva (2010) presented a technique to demonstrate how managerial ability - the ability to run risky projects-could increase total factor productivity and described the pattern of capital flows. The model explained that countries with more high-ability managers applied more risky projects and had higher productivity. The study defined proxies for managerial ability with data on physical and human capital, schooling, and entrepreneurship and predicted similar returns to capital across countries and higher returns in middleincome countries. Hanlon (2005) studied the role of book-tax differences in representing the persistence of earnings, accruals, and cash flows for one-period-ahead earnings. The study also investigated whether the level of book-tax differences affects investors' assessments of future earnings persistence. The study reported that firm-years with large book-tax differences had earnings, which were less persistent than firm-years with small book-tax differences. In addition, the evidence was consistent with investors interpreting large positive book-tax differences as a "red flag" and reducing their expectation of future earnings persistence for these firm-years.

\section{The proposed study}

This paper presents an empirical investigation to measure the effect of managerial ability on earning quality on selected firms listed on Tehran Stock Exchange over the period 2007-2013. In selection of the firms, we have considered some conditions. First, they must be active during the period of study. Second, all necessary information must be available. Third, they must have the same fiscal year there must be no change on their year. In our survey, no financial, insurance, holding or credit union is permitted and they must be all profitable.

\subsection{Data envelopment analysis}

Data Envelpement Analysis (DEA) has been wiedly used for measuring the relative efficiency of different units and there are literally different forms of DEA model. The constant return to scale DEA (CCR) was first introduced by Charnes, et al. $(1978,1994)$ as a mathematical tool for computing the relative efficiency of decision making units (DMU). We may form a set of production feasibility which constituts of some principles such as fixed-scale efficiency, convexity and feasibility as follows,

$$
T_{C}=\left\{(X, Y) \mid X \geq \sum_{j=1}^{n} \lambda_{j} X_{j}, Y \leq \sum_{j=1}^{n} \lambda_{j} Y_{j}, \lambda_{j} \geq 0, j=1, \cdots n\right\},
$$

where $X$ and $Y$ represent the input and output vectors, respectively. The CCR production feasibility set border defines the relative efficiency in which any off-border DMU is considered as inefficient. The CCR model can be studied in two forms of either input or output oriented. The input CCR aims to decrease the maximum input level with a ratio of $\theta$ so that, at least, the same output is produced, i.e.:

$$
\begin{aligned}
& \min \quad \theta \\
& \text { subject to } \\
& \theta X_{p}-\sum_{j=1}^{n} \lambda_{j} X_{i j} \geq 0, \\
& \sum_{j=1}^{n} \lambda_{j} Y_{r j} \geq Y_{r p}, \\
& \lambda_{j} \geq 0, \quad j=1, \cdots, n .
\end{aligned}
$$

Model (2) represents envelopment form of input CCR where $\theta$ is the relative efficiency of the DMU and it is an easy task to demonstrate that the optimal value of $\theta, \theta^{*}$, is always between zero and one. 
In an input oriented DEA model, once the efficiency of a DMU unit, $D M U_{p}$, drops in case of inefficiency, one may directs it towards the border to make it efficient. In the case of the output oriented DEA model, the primary aim is to maximize the output level, $\varphi$, by using the same amount of input. The model can be formulated as follows,

$$
\begin{aligned}
& \min \varphi \\
& \text { subject to } \\
& \sum_{j=1}^{n} \lambda_{j} X_{i j} \leq X_{i p}, \\
& \sum_{j=1}^{n} \lambda_{j} Y_{j} \geq \varphi Y_{i p}, \\
& \lambda_{j} \geq 0, \quad j=1, \cdots, n .
\end{aligned}
$$

The proposed study uses data envelopment analysis to measure the relative efficiency of selected firms where Sales is considered as output and Cost of goods (COGS), Selling, General and Administrative Expenses (SG\&A), Net Property Plant and Equipment (PPE), Net operating Leases (OpsLease), Research \& Development (R\&D), Purchased Good will (Goodwill) and Other intangible assets (OtherIntan) are considered as inputs.

\subsection{Earning quality}

Earning quality in this survey consists of three parts of quality of accruals, earnings and earnings forecast capability.

\subsubsection{Quality of accruals}

According to Dechow and Dichev (2002), quality of earnings is measured through quality of accruals. They proposed the following equation to establish the relationship between total accruals (TCA) and operating cash flow (CFO),

$$
T C A_{i t}=\phi_{0}+\phi C F O_{i t-1}+\phi_{2} C F O_{i t}+\phi_{3} C F O_{i t+1}+V_{i t} .
$$

Here TCA is calculated as follows,

$$
\triangle C A-\triangle C L-\triangle C a s h+\triangle S T D E B T,
$$

where $\triangle C A, \triangle C L, \triangle C a s h$ and $\triangle S T D E B T$ are change in current assets, current liabilities, cash and debt components, respectively. To calculate cash generated from operations, one may calculate cash generated from customers and cash paid to suppliers. The difference between the two reflects cash generated from operations. Quality of accruals is calculated as INVACCQ $=\delta\left(\sqrt{V_{i, t}}\right)$ and higher values of INVACCQ represents lower quality of accruals.

\subsubsection{Quality of earnings}

In our survey, quality of earnings is measured using the method proposed originally by Francis et al. (2003, 2005) as follows,

$$
E A R N_{i, t}=\beta_{0, i}+\beta_{1, i} E A R N_{i, t-1}+\varepsilon_{i, t},
$$


where $E A R N_{i, t}$ and $E A R N_{i, t-1}$ represent the earnings of period $t$ and $t-1$ for firm $i, \beta_{0, i}$ and $\beta_{1, i}$ are coefficients to be estimated and $\varepsilon_{i, t}$ represents the residuals, respectively. When $\beta_{1, i}$ gets close to one, we may expect higher quality for earnings.

\subsubsection{Earnings forecast persistence}

In this survey, earnings forecast capability is measured using Eq. (6) as $\operatorname{INVPRED}=\delta\left(\sqrt{\varepsilon_{i, t}}\right)$. Obviously, higher values for INVPRED represents lower earnings forecast persistence.

\section{The results}

The proposed study of this paper uses regression analysis to study the relationship between managerial ability and earning quality.

\subsection{The first hypothesis: The relationship between quality of accruals and managerial capability}

The first hypothesis of this survey investigates the relationship between quality of accruals as dependent variable and managerial capability as independent variable. The results of our survey is summarized as follows,

$$
\begin{aligned}
& \text { Quality of accruals }=-5.792+0.946 \text { Managerial capability } \\
& \text { t-value } \quad-6.36421 .609 \quad \text { Adjusted R-Square }=0.349 \text { Durbin-Watson }=1.876 \\
& \text { Sig. } \quad 0.000 \quad 0.000 \quad \text { F-value }=462.742(\text { Sig. }=0.000)
\end{aligned}
$$

As we can observe from the results of regression analysis, F-value is statistically significant, which means there is a linear relationship between independent and dependent variable. Durbin-Watson is equal to 1.876, which means there is no correlation among residuals. Adjusted R-Square is equal to 0.349 , which means the independent variable describes approximately $35 \%$ of the changes on dependent variable. Finally, the coefficient of managerial ability is positive with meaningful t-value. This confirms the first hypothesis of this survey.

\subsection{The second hypothesis: The relationship between quality of earnings and managerial capability}

The second hypothesis of this survey studies the relationship between quality of earnings as dependent variable and managerial capability as independent variable. The results of our survey is summarized as follows,

Quality of earnings $=-27.662+0.924$ Managerial capability

$$
\begin{array}{lccc}
\text { t-value } & -73.357 & 9.75 & \text { Adjusted R-Square }=0.357 \quad \text { Durbin-Watson }=1.762 \\
\text { Sig. } & 0.000 & 0.000 & \text { F-value }=93.221(\text { Sig. }=0.000)
\end{array}
$$

As we can see from the results of regression analysis, F-value is statistically significant, which means there is a linear relationship between independent and dependent variable. Durbin-Watson is equal to 1.762, which means there is no correlation among residuals. Adjusted R-Square is equal to 0.357, which means the independent variable describes approximately $35 \%$ of the changes on dependent variable. Finally, the coefficient of managerial ability is positive with meaningful t-value. This confirms the second hypothesis of this survey. 
3.3. The third hypothesis: The relationship between earnings forecast persistence and managerial capability

The third hypothesis of this survey investigates the relationship between earning forecast capability as dependent variable and managerial capability as independent variable. The results of our survey is summarized as follows,

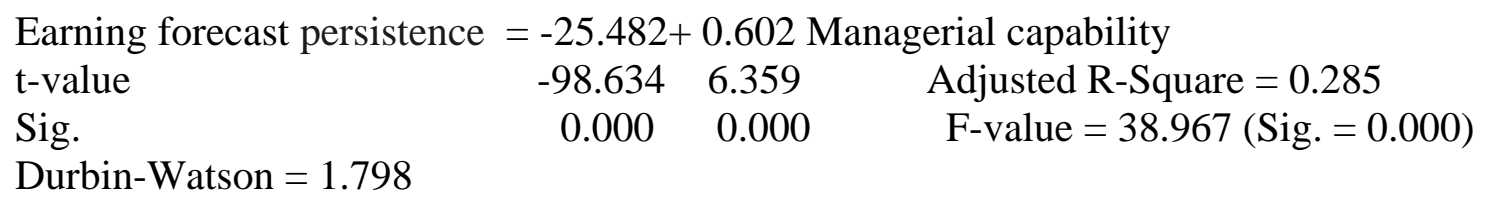

As we can observe from the results of regression analysis, F-value is statistically significant, which means there is a linear relationship between independent and dependent variable. Durbin-Watson is equal to 1.798, which means there is no correlation among residuals. Adjusted R-Square is equal to 0.285 , which means the independent variable describes approximately $29 \%$ of the changes on dependent variable. Finally, the coefficient of managerial ability is positive with meaningful t-value. This confirms the third hypothesis of this survey.

\section{Conclusion}

In this paper, we have presented an empirical investigation to study the relationship between earnings quality and managerial ability on selected firms on Tehran Stock Exchange. The proposed study has implemented DEA technique to measure managerial ability and using the methods in the literature we have measured earnings quality. The results of the survey have confirmed that there were positive and meaningful relationships between quality of accruals and managerial capability, between quality of earnings and managerial capability and finally between earnings forecast capability and managerial capability. The results of this survey are consistent with earlier findings reported by Demerjian et al. (2012) and Siegel (1982).

\section{Acknowledgement}

The authors would like to thank the anonymous referees for constructive comments on earlier version of this paper.

\section{References}

Charnes A, Cooper, W. W., Rhodes, E. (1978). Measuring the efficiency of decision making units. European Journal of the Operational Research, 2, 429-44.

Charnes A, Cooper W. W., Lewin, A., Seiford, L. M. (1994). Data envelopment analysis: theory, methodology and applications. Massachusetts: Kluwer Academic Publishers.

Dechow, P. M., \& Dichev, I. D. (2002). The quality of accruals and earnings: The role of accrual estimation errors. The accounting review, 77(s-1), 35-59.

Demerjian, P., Lev, B., \& McVay, S. (2012). Quantifying managerial ability: A new measure and validity tests. Management Science, 58(7), 1229-1248.

Francis, J., LaFond, R., Olsson, P., \& Schipper, K. (2003). Earnings quality and the pricing effects of earnings patterns. Available at SSRN 414142.

Francis, J., LaFond, R., Olsson, P., \& Schipper, K. (2005). The market pricing of accruals quality. Journal of accounting and economics, 39(2), 295-327.

Hanlon, M. (2005). The persistence and pricing of earnings, accruals, and cash flows when firms have large book-tax differences. The Accounting Review,80(1), 137-166.

Richardson, S. (2003). Earnings quality and short sellers. Accounting Horizons, 17, 4 
Siegel, J. G. (1982). The “Quality of Earnings” Concept-A Survey. Financial Analysts.

Silva, A. C. (2010). Managerial ability and capital flows. Journal of Development economics, 93(1), 126-136. 